
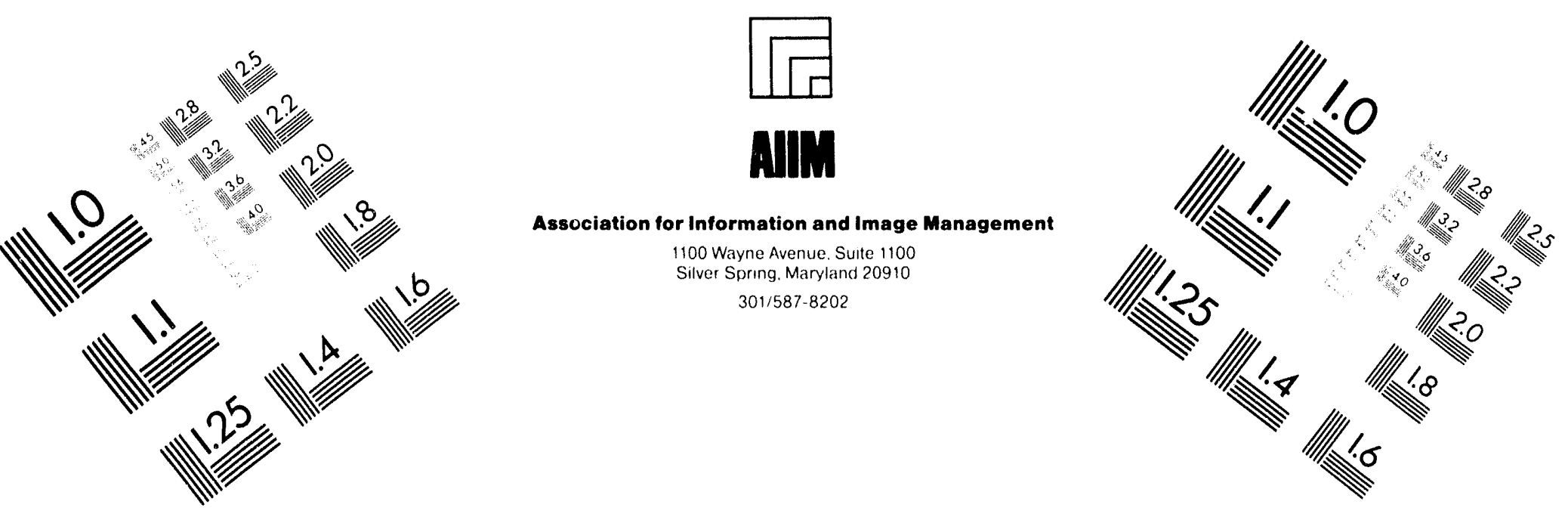

\title{
Centimeter
}

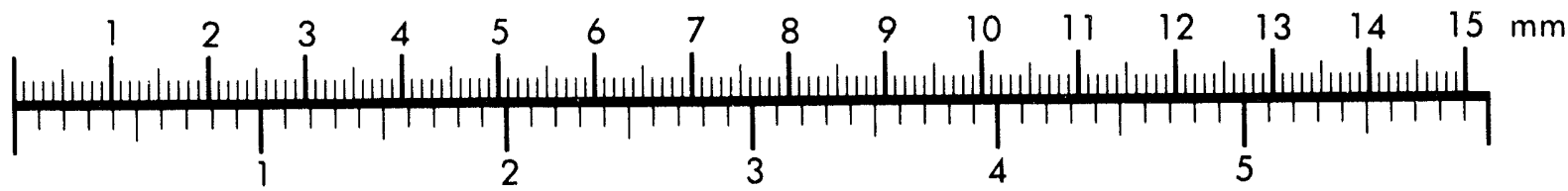

Inches
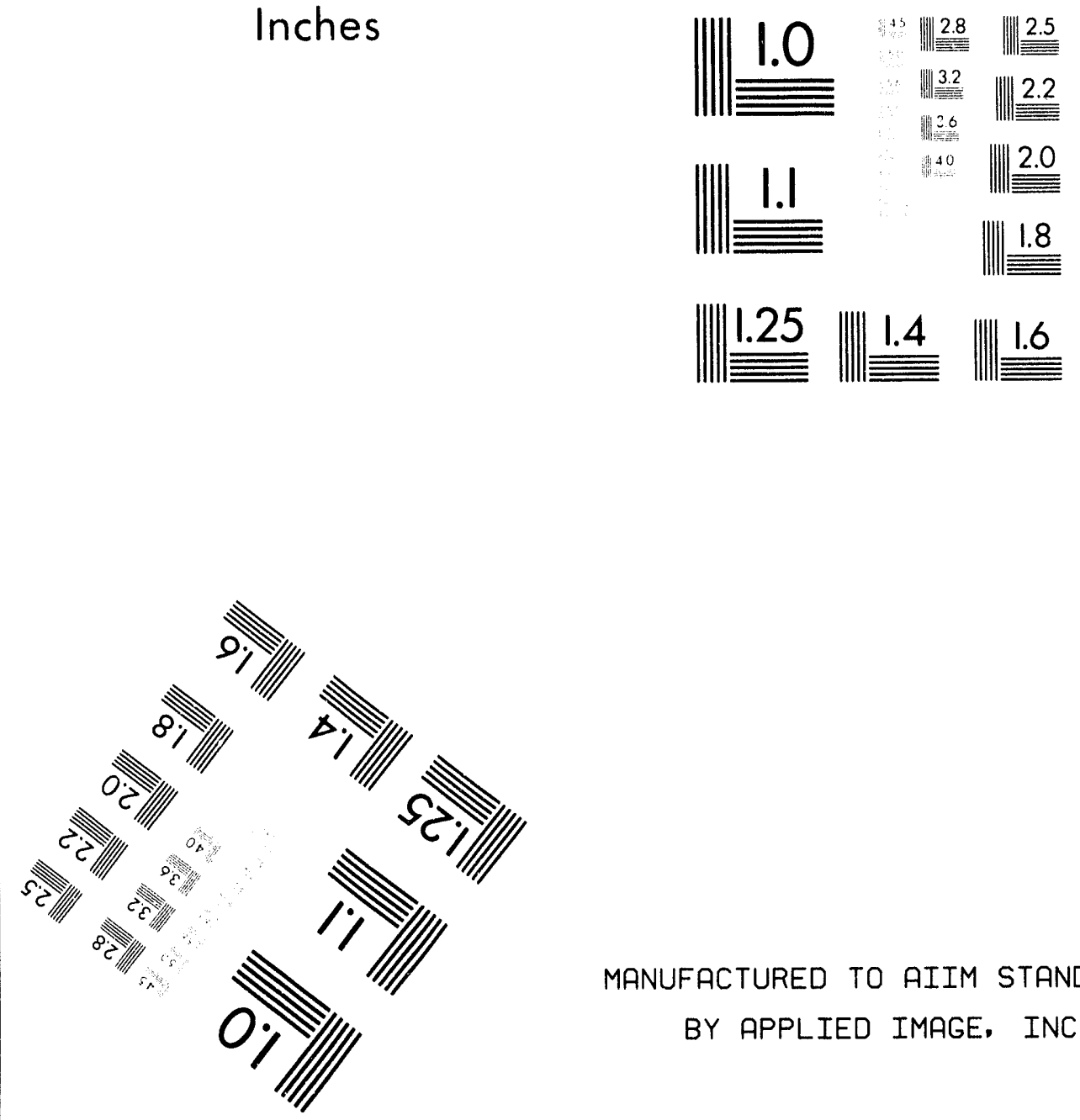

MANUFACTURED TO AIIM STANDARDS BY APPLIED IMAGE. INC.

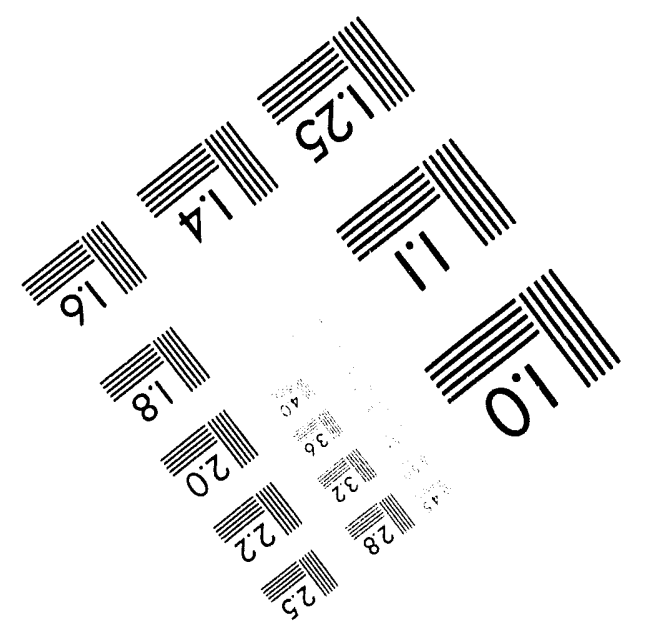



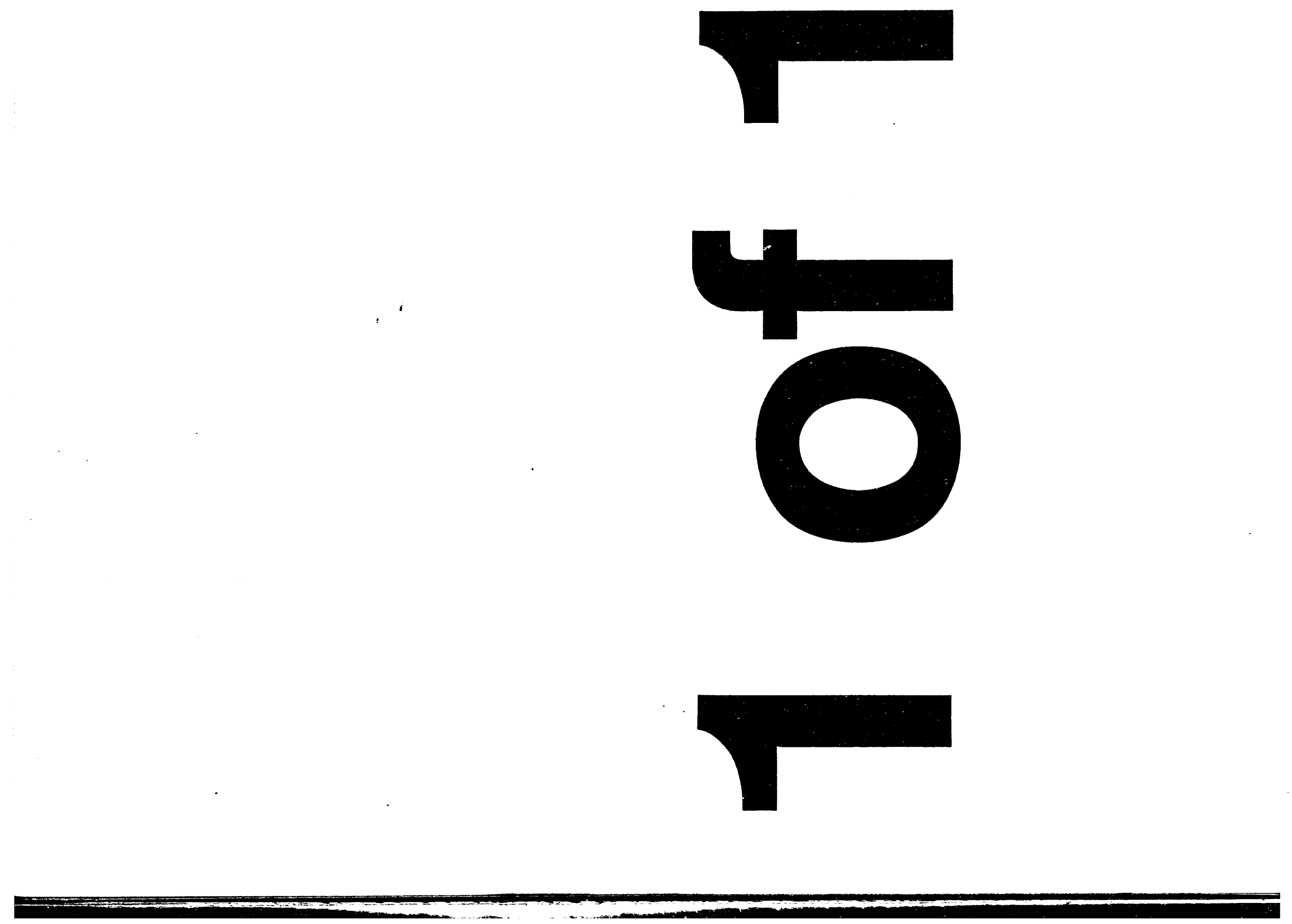


\title{
ANK/CMT/CD. - SO123
}

\section{THE ROLE OF NATURAL GLASSES AS ANALOGUES IN \\ PROJECTING THE LONG-TERM ALTERATION OF HIGH-LEVEL NUCLEAR WASTE GLASSES: PART 1}

James J. Mazer

\section{ARGONNE NATIONAL LABORATORY \\ Chemical Technology Division 9700 South Cass Avenue \\ Argonne, IL 60439}

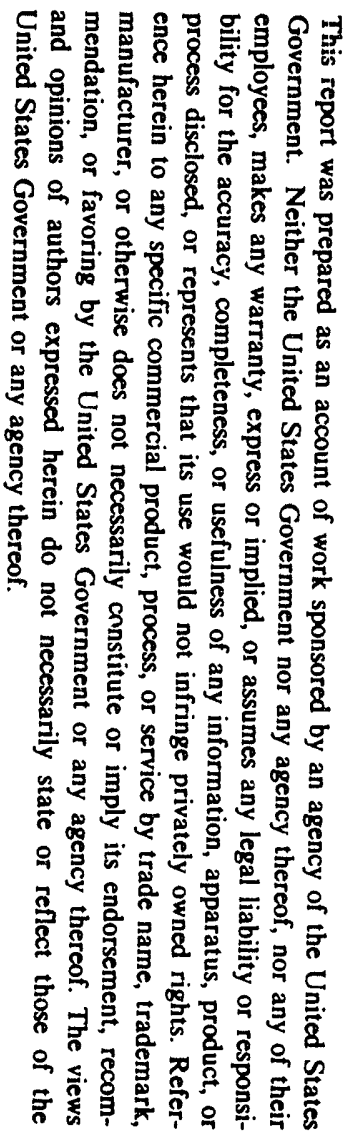

\section{Submitted to \\ 1993 Fall Materials Research Society Meeting \\ Boston, MA \\ November 29-December 3, 1993}

\begin{abstract}
"Work supported by the U.S. Department of Energy, Office of Environmental Restoration and Waste Management, under contract W-31-109-ENG-38.
\end{abstract}

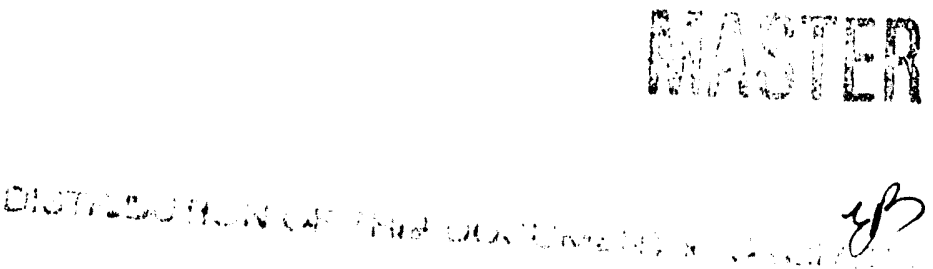




\title{
THE ROLE OF NATURAL GLASSES AS ANALOGUES IN \\ PROJECTING THE LONG-T'ĆRM ALTERATION OF \\ HIGH-LEVEL NUCLEAR W/.STE GLASSES: PART 1
}

James J. Mazer, Chemical Technology Division, Argonne National Laboratory, Argonne, IL 60439 .

\begin{abstract}
The common observation of glasses persisting in natural environments for long periods of time (up to tens of millions of years) provides compelling evidence that these materials can be kinetically stable in a variety of subsurface environments. This paper reviews how natural and historical synthesized glasses can be employed as natural analogues for understanding and projecting the long-term alteration of high-level nuclear waste glasses. The corrosion of basaltic glass results in many of the same alteration features found in laboratory testing of the corrosion of high-level radioactive waste glasses. Evidence has also been found indicating similarities in the rate controlling processes, such as the effects of silica concentration on corrosion in groundwater and in laboratory leachates. Naturally altered rhyolitic glasses and tektites provide additional evidence that can be used to constrain estimates of long-term waste glass alteration. When reacted under conditions where water is plentiful, the corrosion for these glasses is dominated by network hydrolysis, while the corrosion is dominated by molecular water diffusion and secondary mineral formation under conditions where water contact is intermittent or where water is relatively scarce. Synthesized glasses that have been naturally altered result in alkali-depleted alteration features that are similar to those found for natural glasses and for nuclear waste glasses. The characteristics of these alteration features appear to be dependent on the alteration conditions which affect the dominant reaction processes during weathering. In all cases, care must be taken to ensure that the information being provided by natural analogues is related to nuclear waste glass corrosion in a clear and meaningful way.
\end{abstract}

\section{INTRODUCTION}

The ability of nuclear waste glasses to successfully contain high-level radioactive wastes over the service life of a potential geologic repository can not be directly demonstrated in the laboratory. The behavior of these glasses can be projected and extrapolated based on the results of experimental studies. These studies are necessarily performed under conditions that accelerate the reaction in a laboratory time frame. However, there are always uncertainties associated with extrapolations, since the parameter being extrapolated may behave in an unforeseen and unpredictable manner that may not occur, or is not accounted for, in experimental studies.

A way of dealing with these uncertainties has been proposed through the use of natural analogues [1-3]. The common observation of natural and synthetic glasses, persisting in natural environments for long periods of time (tens of millions of years) provides compelling evidence that glasses can be kinetically stable in a variety of subsurface environments. If it can be shown that the natural alteration of glasses and the experimental alteration of glasses proceed by similar reaction mechanisms, then naturally altered samples can be used to help understand and project the long-term alteration behavior of glasses. By establishing a credible means of understanding the 
relationship between mechanistic observations of naturally altered glasses and experimentally altered glasses, one can project long-term durability by analogy [1-6].

\section{Natural Analogue Approach}

Relating naturally altered glasses to potential alteration of glass waste forms can be accomplished through a process-oriented natural analogue approach $[3,4]$, even though the naturally altered glass may be compositionally dissimilar to nuclear waste glass. All natural analogue studies incorporate some or all aspects of this approach. Two criteria are commonly employed in understanding reaction mechanisms and comparing the alteration: (1) Comparison of reaction products and (2) comparison of reaction kinetics. Research and programmatic needs of natural analogue studies sometimes vary and, consequently, natural analogue studies frequently emphasize these criteria differently. The approach is graphically illustrated in Figure 1.

A important step in natural analogue studies is the development of a means of experimentally altering natural samples by the same reaction mechanism as occurs in nature. Experiments are usually necessarily performed at accelerated rates so it is crucial to establish that the reaction mechanisms are identical. The similarity of the reaction mechanisms is usually evaluated by investigating both the reaction products and the reaction kinetics. Once experimental techniques for natural samples are developed, then the nuclear waste glasses of interest are experimentally altered, using the same techniques. Detailed surface characterizations and studies of the reaction kinetics for the glass waste forms are then used to derive information that can be used to project performance under conditions experienced by the long-lived natural analogues.

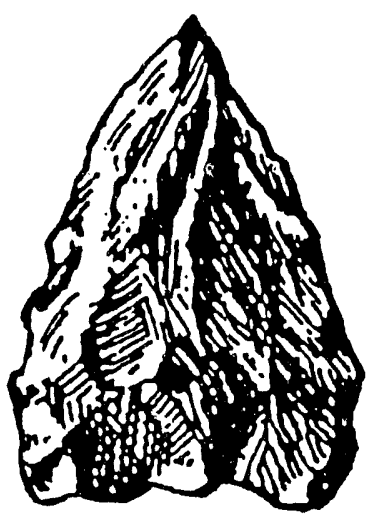

Naturally

Reacted Glass



Experiments Natural Glass

Figure 1. Schematic Diagram Depicting a Natural Analogue Approach. The alteration that produces naturally reacted glasses is compared to that found for experimentally altered glasses by comparing the reaction kinetics and alteration mineral formation. Once it has been ascertained that experimental alteration proceeds by a reaction mechanism identical to that which naturally occurs, there is a basis for using that experimental alteration technique to provide waste glass observations that can be used to project long-term waste glass performance. 
In a process-oriented natural analogue study, the information derived can be used to assess the long-term effects of a particular reaction process. Although the reaction process found in the long-lived natural analogue may not be dominant in a nuclear waste glass on the short-term experimental time scale, an understanding of this reaction process can allow modelers to determine when, if ever, the reaction process does become dominant or important.

\section{Natural Glasses}

Natural glasses are generally classified according to their silicon contents, ranging from silica-rich rhyolitic glasses (obsidian) and tektites to silica-poor basalt glasses (sideromelane). Typical compositions of each of these types of glasses are presented in Table I. A representative waste glass, SRL 165, is included for comparison.

\section{Basalt Glasses}

Basalt glasses are found in a variety of natural environments that span a significant range temperature, surface area to solution volume ratio $(S / N)$, contacting solution compositions and exposure time. The known ages of basalt glasses typically range up to millions of years [11-15]. The bases for using basalt glasses as analogues are the similarities in compositions and the similarities in actual and expected reaction conditions for HLW glasses and those observed for many naturally altered basalt glasses.

Table I. Typical Compositions of Natural Analogue Glasses in weight \%. The Glass Compositions are reported in references $[7,7,7,8,9,10,7]$, respectively.

\begin{tabular}{|c|c|c|c|c|c|c|c|}
\hline & $\begin{array}{l}\text { Basalt } \\
\text { Glass }\end{array}$ & $\begin{array}{l}\text { Rhyolitic } \\
\text { Glass }\end{array}$ & Tektite & $\begin{array}{l}\text { Egyptian } \\
\text { Bead }\end{array}$ & $\begin{array}{l}\text { Roman } \\
\text { Bottle } \\
\text { Glass }\end{array}$ & $\begin{array}{l}\text { Tiffany } \\
\text { Window } \\
\text { Glass }\end{array}$ & $\begin{array}{l}\text { SRL } 165 \\
\text { Glass }\end{array}$ \\
\hline $\mathrm{SiO}_{2}$ & 50.7 & 74.9 & 74.4 & 64.75 & 68.48 & 43.3 & 52.86 \\
\hline $\mathrm{Al}_{2} \mathrm{O}_{3}$ & 11.7 & 14.2 & 12.17 & 0.62 & 2.61 & 2.0 & 4.08 \\
\hline $\mathrm{B}_{2} \mathrm{O}_{3}$ & -- & -.. & 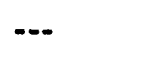 & -.. & -.. & 11.5 & 6.76 \\
\hline $\mathrm{Na}_{2} \mathrm{O}$ & 4.5 & 4.68 & 1.32 & 19.43 & 19.73 & 0.2 & 10.85 \\
\hline $\mathrm{K}_{2} \overline{\mathrm{O}}$ & 0.7 & 4.59 & 2.61 & 1.66 & 0.77 & 2.7 & 0.19 \\
\hline $\mathrm{CaO}$ & 10.6 & 0.53 & 1.52 & 7.23 & 6.74 & 0.35 & 1.62 \\
\hline $\mathrm{MgO}$ & 6.7 & 0.02 & 1.85 & 2.53 & 0.68 & 0.03 & 0.70 \\
\hline $\mathrm{FeO}$ & $\cdots$ & 0.49 & $\cdots$ & $\cdots$ & 0.29 & 0.09 & $\cdots$ \\
\hline $\mathrm{Fe}_{2} \mathrm{O}_{3}$ & 13.1 & 0.29 & 5.58 & 0.31 & $\ldots$ & $\ldots$ & 11.74 \\
\hline $\mathrm{TiO}_{2}$ & 1.9 & 0.04 & 0.76 & $\cdots$ & $\ldots$ & 0.1 & 0.14 \\
\hline $\mathrm{MnO}$ & 0.4 & 0.03 & 0.11 & 0.02 & 0.65 & $\ldots$ & 2.79 \\
\hline $\mathrm{P}_{2} \mathrm{O}_{5}$ & $\cdots$ & $\cdots$ & -- & $\cdots$ & $\cdots$ & 0.26 & 0.02 \\
\hline $\mathrm{Li2O}$ &.-- & --. & -.- & $\cdots$ & -- & $\ldots$ & 4.18 \\
\hline $\mathrm{NiO}$ & $\cdots$ & $\cdots$ & $\cdots$ & $\cdots$ & $\cdots$ & -.- & 0.85 \\
\hline $\mathrm{ZrO}_{2}$ & $\cdots$ & -- & $\cdots$ & $\cdots$ & $\cdots$ & -.- & 0.66 \\
\hline $\mathrm{PbO}$ & --- & -.- & $-\cdots$ & -.. & ... & 38.93 & $\cdots$ \\
\hline $\mathrm{CuO}$ & $\cdots$ & $\ldots$ & -.. & 1.55 & $<0.06$ & 0.06 & $\ldots$ \\
\hline $\mathrm{H}_{2} \mathrm{O}$ & 0.1 & 0.3 & 0.01 & $\ldots$ & -.- & -.. & 0.1 \\
\hline
\end{tabular}


Basalt glasses are the natural glasses that are compositionally most similar to proposed nuclear waste glasses, Table I. The range of reaction conditions encountered for basalt glasses on earth can be classified into three general groups: (1) submarine exposures, where the reacting soiution contains alkaii salts; (2) subaerial exposures where the glass is constantly or intermittently exposed to meteoric (fresh) water; and (3) some combination of subaerial and submarine exposures. These cases constitute conditions that likely bracket the conditions that HLW glasses will be exposed to in a potential geologic repository (i.e., SN ratios ranging from very large to very small; contacting solution ranging in composition from concentrated to dilute; periods of time bounding the potential repository lifetime).

Basalt glass alteration and its possible relationship to possible HLW glass corrosion has been the subject of a number of studies [e.g., 11-16]. Naturally altered basalt glasses commonly form a poorly crystalline alteration material called palagonite that is widely variable in composition and appearance. This material has been found to be nearly identical in composition to intergranular clays associated with the original glass [15]. Palagonite has been found to be the natural analogue to gel layers found on borosilicate glasses [15]. A second common alteration product associated with naturally altered basalt glass is secondary minerals. Reaction conditions may preclude secondary mineral formation [e.g., 17], however, many studies have found secondary minerals on basalt glasses that correspond to secondary mineral phases found on laboratory altered HLW glasses $[12,15,18,19]$.

\section{Rhyolitic Glasses}

Rhyolitic glasses have been considered as natural analogues for waste glass alteration in experimental and field studies. In general, experimentally determined rhyolitic glass leach rates are lower than those for proposed nuclear waste glasses $[20,21]$. There is no clear consensus as to the dominant reaction process for rhyolitic glasses in small SN experimental corrosion conditions. Ion exchange $[22,23]$, congruent dissolution (network hydrolysis) [20] and secondary mineral formation $[21,24,25]$ are among the processes reported for these reactions. Among the alteration minerals associated with weathered rhyolitic glasses are alkali depleted Fe-rich aluminosilicates, mica minerals, epidote, alkali feldspars and $\mathrm{Al}(\mathrm{OH}) 3[21,24]$. A common observation on naturally and experimentally altered rhyolitic glasses is an alkali-depleted aluminosilicate phase that partly retains calcium and alkaline earth elements [26]. This phase is attributed to molecular water diffusion and ion exchange, reaction processes common to waste glass corrosion [26,27].

The experimental corrosion of rhyolitic glass with water in large $\mathrm{S} N$ conditions is dominated by molecular water diffusion $[25,28]$. This reaction process also occurs in naturally altered rhyolitic glasses for long periods of time (up to $10^{4}$ years) [22] and forms the basis for a dating technique. Studies of naturally altered rhyolitic glass $\left(5.2 \times 10^{3}\right.$ years) have concluded that ion exchange is the long-term rate controlling reaction process for low temparature aqueous corrosion conditions, conditions similar to those possible for a geologic repository [26].

Molecular water diffusion is a reaction associated with nuclear waste glass corrosion $[27,29,30]$ that may be important during the waste glass service life. The temperature and relative humidity effects of molecular water diffusion have been determined for rhyolitic glasses [25]. These data have been used to make preliminary assessments of the potential importance of water diffusion on lony-term waste glass corrosion under coriditions of low SN. 
Occurrences of tektites are rarer than for rhyolitic glasses but are of importance owing to the great age of tektites ( 0.7 to 365 million years before present). The reaction processes responsible for tektite alteration in laboratory and experimental studies include molecular water diffusion, network hydrolysis, and secondary mineral precipitation [31-34]. The relative importance of the different reaction processes is dependent on the reaction conditions, particularly the $S N$ ratio. Network hydrolysis dominates under $S N$ conditions where water is plentiful [31-33] (e.g., submarine exposures), while molecular water diffusion and secondary mineral precipitation dominate under unsaturated conditions where $S N$ is relatively small or exposure to water is intermittent [34]. The secondary minerals associated with small SN weathering are identical in natural $[35,36]$ and experimental studies [34]. This observation is consistent with the assertion that low $S N$ experiments reproduce in a laboratory time frame the long-term natural alteration conditions. The extraordinary durability observed for naturally altered tektite has been attributed to factors such as low intrinsic water content [31,34], and high silica and low alkali content [34].

\section{SUMMARY}

Natural analogue studies provide information that can be used to assist in the long-term projection of nuclear waste glass corrosion. This information is in the form of alteration phases and kinetics that can be used to diagnose the reaction mechanism. Arguments relating the observations of naturally altered glass to the projection of nuclear waste glass corrosion must ensure that the reaction processes are the same in both cases. Similarly, natural alteration conditions need to be considered in relation to those used in nuclear waste glass experiments.

As a result of natural weathering, the bulk synthetic glass compositions altered and form layers that are completely depleted in sodium and potassium and enriched in $\mathrm{Fe}$ and $\mathrm{Mn}$ by up to a factor of ten [37]. These alteration features form as a result of molecular water and alkali interdiffusion, reaction processes identical to those found in nuclear waste glass alteration. The observation that naturally altered synthetic glasses forms a silicon hydroxide-rich gel is consistent with observation of gel-like materials forming on basalt glasses (palagonite) [15-19], rhyolitic glasses [23,26] and on nuclear waste glasses $[12,15,20]$. Clay minerals are also reported to be found on natural glasses [14,15,17,22,34,35], synthetic glasses [8-10,37] and nuclear waste glasses [1,57]. Natural and experimental corrosion results in common alteration features that also suggest that similar or identical reaction processes are occurring on natural, synthetic and nuclear waste glasses. These findings provide compelling evidence that there is a basis for using natural analogue studies to project long-term glass behavior. Natural analogue studies can provide confidence that natural reaction mechanisms are the same as those studied in laboratory experiments. When used correctly, they can provide some reassurance regarding the pertinence and relevance of waste glass experiments.

\section{ACKNOWLEDGMENTS}

Work supported by the U.S. Department of Energy, Office of Environmental Restoration and Waste Management, under contract W-31-109-ENG-38. 


\section{REFERENCES}

1. R. C. Ewing, Sci, Basis for Nucl. Waste Mgmt. G. J. McCarthy, (Ed.), Plenum Press, New York, 57 (1978).

2. J.-C. Petit, Appl. Geochem. Suppl Issue 1, 9 (1992).

3. N. A. Chapman, I. G. McKinley, and J. A. T. Smellie, The Potential of Natural Analogues in Assessing Systems for Deep Disposal of High-Level Radioactive. Waste, NAGRA Technical Report NTB 84-41 (1984).

4. N. A. Chapman and J. A. T. Smellie, Chem. Geol. 55, 167 (1986).

5. W. F. McKenzie, Natural Glass Analogues to Alteration of Nuclear Waste Glass: A Review and Recommendations for Further Study, Lawrence Livermore National Laboratory Report UCID-21871 (1990).

6. E. C. Pearcy and W. M. Murphy, Geochemical Natural Analogi Literature Review, Center for Nuclear Waste Regulatory Analyses Repo t CNWRA 90-008 (1991).

7. J. C. Cunnane (Ed.), High-Level Waste Borosilicate Glass: A zompendium of Corrosion Characteristics. Volume II, Argonne National Labo atory Report (in press).

8. P. B. Vandiver, C. P. Swann, D. Cramer, Mater. Issues in Art and Arch. II, Mater. Res. Soc. Symp. Proc. 185, 609 (1991).

9. P. B. Vandiver, Corrosion of Glass. Ceramics and Superconductors, D. E. Clark and B. K. Zoitos (Eds.), Noyes Press, Park Ridge NJ, 393 (1992).

10. W. D. Kingery and P. B. Vandiver, Applications of Science in Examination of Works of Art, P. A. England and L. Van Zelst (Eds.), Museum of Fine Arts, Boston, 100 (1985).

11. R. C. Ewing and M. J. Jercinovic, Sci. Basis for Nucl. Waste Mgmt. X, J. K. Bates and W. B. Seefeldt (Eds.), Mat. Res. Soc., Pittsburgh, 67, (1987).

12. C. B. Byers, M. J. Jercinovic, and R. C. Ewing, A Study of Natural Glass Analogues as Applied to Alterations of Nuclear Waste Glass, Argonne National Laboratory Report ANL-86-46 (1987).

13. C. Allen, Sci. Basis for Nucl. Waste Mamt. V, W. Lutze (Ed.), Mat. Res. Soc., Pittsburgh, 37 (1982).

14. T. E. Keith and L. W. Staples, Clay and Clay Min. 33, 135 (1985).

15. J. L. Crovisier, J. Honnorez, B. Fritz and J. -C. Petit, Appl. Geochem. Suppl. Issue 1, 55 (1992).

16. J. L. Crovisier, J. Honnorez, and J. P. Eberhart, Geochim. Cosmo. Acta 51, 2977 (1987).

17. S. R. Gislason and H. P. Eugster, Geochim. Cosmo. Acta 51, 2827 (1987).

18. W. Lutze, G. Malow, R. C. Ewing, M. J. Jercinovic and K. Keil, Nature 314,252 (1985).

19. M. J. Jercinovic and R. C. Ewing, Basaltic Glasses from Iceland and Deep Sea: Natural Analogues to Borosilicate Nuclear Waste-Form Glass, Japanese Swiss Swedish Project Technical Report JSS-88-01 (1987).

20. G. Malow, W. Lutze, and R. C. Ewing, J. Non-Cryst. Sol., 67, 305 (1984).

21. S. N. Karkhanis, G. M. Bancroft, W. S. Fyfe and J. D. Brown, Nature 284, 435 (1980).

22. I. Friedman, and W. Long, J. Non-Cryst. Sol. 67, 127 (1984).

23. A. F. White and H. C. Claassen, Chem. Geol. $\underline{28}, 91$ (1980).

24. A. P. Dickin, Nature 294,342 (1981).

25. J. J. Mazer, J. K. Bates, C. R. Bradley and C. M. Stevenson, J. Nucl. Mater 190, 277 (1992) 
26. M.-C. Magonthier, J. -C. Petit, and J. -C. Dran, Appl. Geochem Suppl Issue 1, 83 (1992).

27. T. A. Abrajano, J. K. Bates, and J. J. Mazer, J. Non-Cryst. Sol. 108, 269 (1989).

28. J. J. Mazer, J. K. Bates, C. M. Stevenson and C. R. Bradley, Sci. Basis for Nucl. Waste Mgmt. XV, C. Sombret. (Ed.), Mat. Res. Soc., Pittsburgh, 513 (1992).

29. J. -C. Dran, G. Della Mea, A. Paccagnella, J. -C. Petit, and L. Trotignon, Phys. Chem Glasses 29(6), 249 (1988).

30. J. -C. Petit, G. Della Mea, and A. Paccagnella, Chem. Geol. 78, 219 (1990).

31. Aa. Barkatt, M. S. Boulos, Al. Barkatt, W. Sousanpour, M. A. Boroomand, P. B. Macedo, and J. A. O'Keefe, Geochim. et Cosmo. Acta 48, 361 (1984).

32. P. LaMarche, F. Rauch, and W. A. Lanford, J. Non-Cryst. Sol. 67,361 (1984).

33. F. Rauch, J. E. Ericson, W. Wagner, C. Grimm-Leimsner, R. P. Livi, C. Shi and T. A. Tombrello, J. Non-Cryst. Sol. 144, 224 (1992).

34. J. J. Mazer, J. K. Bates, J. P. Bradley, C. R. Bradley, and C. M. Stevenson, Nature 357,573 (1992).

35. H. Sigurdsson, S. D'hondt, M. A. Arthur, T. J. Bralower, J. C. Zachos, M. Van Fossen, and, J. E. T. Channell, Nature 349, 482 (1991).

36. G. Izett, G. Dalrymple and L. Snee, Science 252, 1539 (1991).

37. P. B. Vandiver, this volume (1994). 




$$
\text { L }
$$

